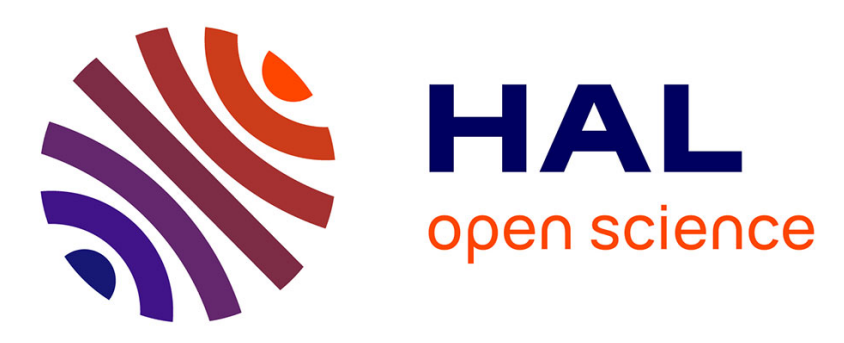

\title{
A Structural and Functional Model for the 1-Aminocyclopropane-1-carboxylic Acid Oxidase
}

Madleen Sallmann, Fabio Oldenburg, Beatrice Braun, Marius Réglier, A. Jalila Simaan, Christian Limberg

\section{- To cite this version:}

Madleen Sallmann, Fabio Oldenburg, Beatrice Braun, Marius Réglier, A. Jalila Simaan, et al.. A Structural and Functional Model for the 1-Aminocyclopropane-1-carboxylic Acid Oxidase. Angewandte Chemie International Edition, 2015, 54 (42), pp.12325 - 12328. 10.1002/anie.201502529 . hal-01475561

\author{
HAL Id: hal-01475561 \\ https://hal.science/hal-01475561
}

Submitted on 2 Feb 2022

HAL is a multi-disciplinary open access archive for the deposit and dissemination of scientific research documents, whether they are published or not. The documents may come from teaching and research institutions in France or abroad, or from public or private research centers.
L'archive ouverte pluridisciplinaire HAL, est destinée au dépôt et à la diffusion de documents scientifiques de niveau recherche, publiés ou non, émanant des établissements d'enseignement et de recherche français ou étrangers, des laboratoires publics ou privés. 


\title{
A structural and functional model for the 1-aminocyclopropane-1- carboxylic acid oxidase
}

\author{
Madleen Sallmann, Fabio Oldenburg, Beatrice Braun, Marius Réglier, A. Jalila Simaan*, Christian \\ Limberg*
}

\begin{abstract}
The hitherto most realistic low-molecular weight analogue for the ACCO is reported. The ACCOs 2-His-1-carboxylate iron(II) active site was mimicked by a TpFe moiety, to which the natural substrate ACC could be bound. The resulting complex $\left[T p^{M e, P h} \mathrm{FeACC}\right], 1$, according to a $X$-ray diffraction analysis performed for the nickel analogue, represents an excellent structural model, featuring ACC coordinated in a bidentate fashion - as proposed for the enzymatic substrate complex - as well as a vacant coordination site that forms the basis for the first successful replication also of the ACCO function: 1 is the first known ACC complex that reacts with $\mathrm{O}_{2}$ to produce ethylene. As $\mathrm{FeOOH}$ species had been suggested as intermediates of the catalytic cycle, $\mathrm{H}_{2} \mathrm{O}_{2}$ was tested as the oxidant, too, and indeed evolution of ethylene proceeded even more rapidly with $65 \%$ yield.
\end{abstract}

Ethylene is a gaseous hormone for plants that induces their ripening. ${ }^{[1]}$ It is produced from the amino acid 1-aminocyclopropane-1-carboxylic acid, through oxidation with $\mathrm{O}_{2}$ as the oxidant and ascorbate as the coreductant, mediated by the enzyme 1-aminocyclopropane-1-carboxylic acid oxidase (ACCO). ${ }^{[2]} \mathrm{CO}_{2}$ and $\mathrm{HCN}$ are generated concomitantly (Scheme 1). For not well-understood reasons, the enzyme also requires $\mathrm{CO}_{2}$ (or bicarbonate ions) to develop its reactivity.

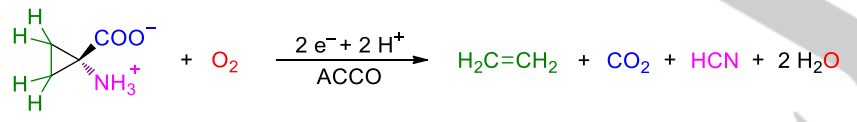

Scheme 1. The biosynthesis of ethylene.

The crystal structure of the ACCO from Petunia hybrida has been determined in 2004 by Schofield and coworkers. ${ }^{[3]}$ It belongs to the family of non-heme iron enzymes featuring a structural motif termed the 2-His-1-carboxylate facial triad: The active center contains an iron(II) ion coordinated by two histidine moieties and

\footnotetext{
Dr. M. Sallmann, B. Sc. F. Oldenburg, Dr. B. Braun,

Prof. Dr. C. Limberg

Humboldt-Universität zu Berlin

Institut für Chemie

Brook-Taylor-Strasse 2, 12489 Berlin (Germany)

E-mail: Christian.limberg@chemie.hu-berlin.de

Homepage: http://www.chemie.hu-berlin.de/aglimberg

Dr. M. Regliér, Dr. J. Simaan

Aix Marseille Université, CNRS, Centrale marseille

Institut des Sciences Moléculaires de Marseille

iSm2 UMR 71313, 13397 Marseille (France)

E-mail: jalila.simaan@univ-amu.fr

Homepage: http://ism2.univ-amu.fr/pages-bleues/index2.htm
}

one aspartate residue in a facial arrangement, leaving the other three sites of the iron ion vacant for the binding of ACC and potentially $\mathrm{O}_{2}$. The mechanism, by which the complex conversion of Scheme 1 is realized, is still discussed controversially, but it is generally assumed that the oxidation of ACC into ethylene follows a radical mechanism including two successive single electron oxidation steps. ${ }^{[4]}$ Spectroscopic studies have revealed that in the first step of the reaction the substrate ACC binds to the $\mathrm{Fe}^{\text {Il }}$ ion in a bidentate mode most likely followed by $\mathrm{O}_{2}$ activation to generate

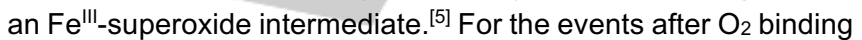
several suggestions have been made that all involve an $\mathrm{Fe}^{\mathrm{IV}}=\mathrm{O}$ intermediate but differ in the sequence of the electron transfer steps with ascorbate and in the nature of the intermediates responsible for the successive oxidation of ACC. Rocklin et al. have proposed that binding of $A C C$ and $\mathrm{O}_{2}$ is followed by one electron reduction to provide an iron(III)-hydroperoxide intermediate that performs the first ACC oxidation step leading to an $\mathrm{Fe}^{\mathrm{IV}}=\mathrm{O}$ species responsible for the second oxidation step. ${ }^{\left[{ }^{[6]}\right.}$ One electron from ascorbate would then complete the catalytic cycle. Alternatively, Mirica et. al. have proposed an ascorbatedependent formation of the $\mathrm{Fe}^{\mathrm{IV}}=\mathrm{O}$ intermediate that would act as the first oxidizing species. ${ }^{[7]}$ Many questions thus remain unanswered regarding the interaction mode with the substrate, the role of the different cofactors/co-substrates (ascorbic acid, dioxygen and carbon dioxide) and the catalytic mechanism.

Bioinorganic model studies can provide valuable information, both with regard to structural issues and requirements for reactivity. However, there are hardly any compounds known which may be regarded as models of ACCO, applying the minimum condition, that they contain ACC and that they display substantial ACCO-like activities. ${ }^{[8,9]}$ One iron complex has been reported, which is dinuclear, though, contains iron(III) ions and two bridging ACC ligands. ${ }^{[8]}$ While iron(II) complexes have long remained unknown, mononuclear 1:1 metal-ACC complexes have been accessed for copper(II). ${ }^{[9]}$ An Fe"-ACC complex has very recently been described, but it can hardly be considered as a functional replicate of the ACCO: the iron centre is coordinated octahedrally by six donor atoms, and hence oxidants have not access to the iron centre. This explains that no reactivity with $\mathrm{O}_{2}$ was observed and that the yield of ethylene produced in reactions with $\mathrm{H}_{2} \mathrm{O}_{2}$ was only $7 \%$ higher as compared to the blank experiments. ${ }^{[10]}$

To mimic mononuclear non-heme iron dioxygenases based on a 3-His structural motif we have in recent years successfully employed the tris(pyrazolyl)borato (Tp) ligand system, ${ }^{[11]}$ which in the past has also been employed already to simulate representatives based on the 2-His-1-carboxylate structural motif. ${ }^{[12]}$ It thus appeared a promising choice also for the development of replicates of the ACCO. One problem that has 
emerged in the past with regard to the modeling of this enzyme is the tendency of ACC to bridge two metal centers, so that the model character of the resulting complexes is reduced (vide supra). Hence, we chose phenyl residues at the 3-positions of the pyrazole donors within $\mathrm{Tp}$ to create a shielding reaction pocket approaching the situation in the enzyme. A suitable starting material was therefore the complex $\left[\mathrm{Tp}^{\mathrm{Me}, \mathrm{Ph}} \mathrm{FeCl}\right]^{[13]}\left(\mathrm{Tp}^{\mathrm{Me}, \mathrm{Phe}}=3-\right.$ Phenyl-5-methylhydrido-trispyrazol-1-ylborato), which after dissolution in dichloromethane was reacted with the potassium salt of the amino acid 1-amino-cyclopropane-1-carboxylic acid (see Scheme 2).

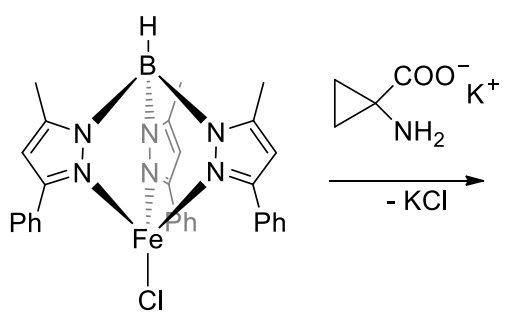

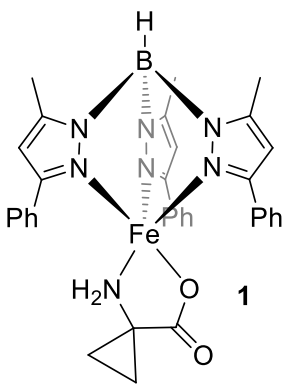

Scheme 2. Synthesis of [Tp $\left.{ }^{\mathrm{Me}, \mathrm{Ph}} \mathrm{FeACC}\right], 1$.

After work-up a light yellow solid was isolated, which was characterized by elemental analysis, IR and ${ }^{1} \mathrm{H}$ NMR spectroscopy (see Supplementary information). The IR spectrum showed characteristic bands for the $\mathrm{NH}_{2}$ stretching vibrations as well as for the carboxylate absorptions, and the $v(\mathrm{BH})$ band, which is typical for $\mathrm{Tp}$ complexes and sensitive to the environment, appeared at $2549 \mathrm{~cm}^{-1}$. While all analytical and spectroscopic data pointed to the envisaged complex [ $\left.\mathrm{Tp}^{\mathrm{Me}, \mathrm{Ph}} \mathrm{FeACC}\right]$, 1, all attempts to crystallize this compound led to crystals of $\left[\mathrm{Tp}^{\mathrm{Me}, \mathrm{Ph}}{ }_{2} \mathrm{Fe}\right]$ To clarify whether the latter complex represents an impurity that has favorable crystallization properties, or whether it forms via ligand exchange during attempts to crystallize 1, it was prepared independently and characterized by ${ }^{1} \mathrm{H}$ NMR spectroscopy. Comparison showed that $\left[\mathrm{Tp}^{\mathrm{Me}, \mathrm{Ph}}{ }_{2} \mathrm{Fe}\right]$ was not present in freshly prepared samples of 1 and neither it was after $7 \mathrm{~h}$, but after storing of solutions for 5 days [ $\mathrm{Tp}^{\mathrm{Me}, \mathrm{Ph}}{ }_{2} \mathrm{Fe}$ ] could be detected in significant amounts. This clearly showed that $\mathbf{1}$ is stable enough in solution for reactivity studies but does not readily crystallize, and crystallization can neither be achieved by allotting additional time as this leads to ligand exchange. Mössbauer spectroscopy was used to further characterize the complex. The spectrum of 1 in acetonitrile was recorded and is characterized by quadrupoledublett with an isomeric shift $\delta=1.0906 \mathrm{~mm} / \mathrm{s}$ and an electronic quadrupole splitting of $\Delta \mathrm{Eq}=2.7 \mathrm{~mm} / \mathrm{s}$ typical of high-spin iron(II) species.

In order to obtain structural information we have thus prepared a corresponding nickel complex [Tp $\left.{ }^{\mathrm{Me}, \mathrm{Ph}} \mathrm{NiACC}\right], \mathbf{2}$, in the same way setting out from [ $\left.\mathrm{Tp}^{\mathrm{Me}, \mathrm{Ph}} \mathrm{NiBr}\right]$ (see Supplementary information). After work-up of the blue-green reaction solution a light green solid could be isolated, which showed an almost identical IR spectrum as compared to the one displayed by 1 , with respect to band shape, pattern and intensities. Since this indicated that the structure of $\mathbf{2}$ is rather similar to the one of $\mathbf{1}$, too, a structural investigation of $\mathbf{2}$ was of high interest.

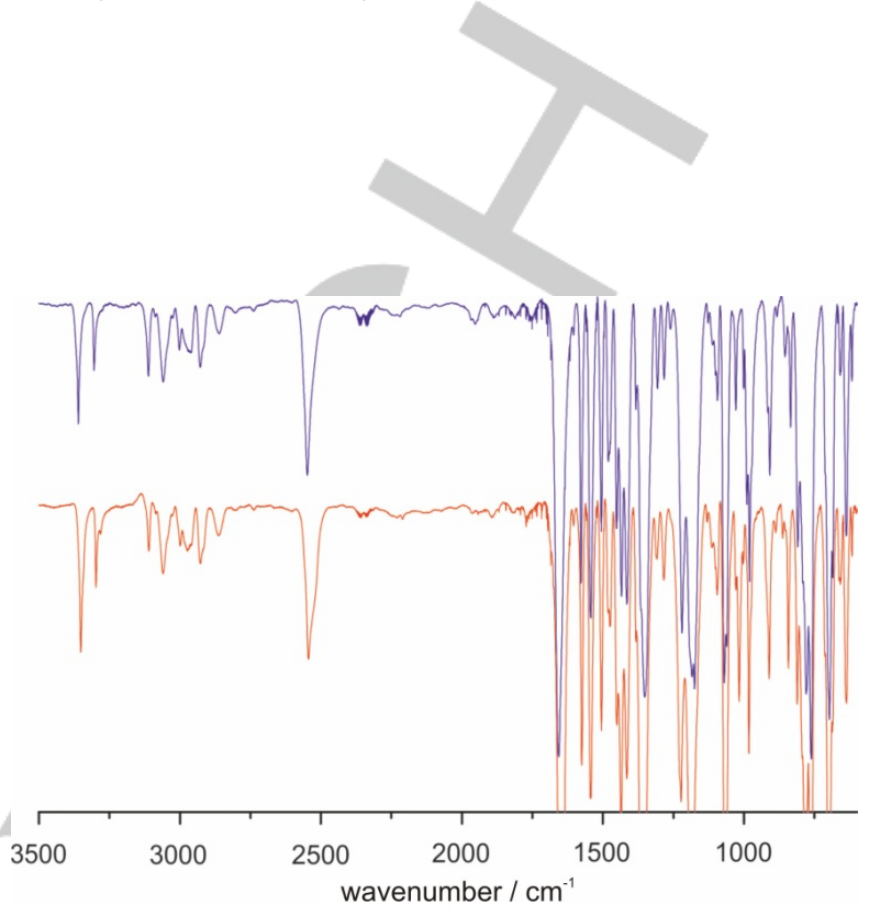

Figure 1. Comparison of the IR spectra of 1 (blue) and 2 (red) as recorded for $\mathrm{KBr}$ discs.

2.thf could be crystallized through overlaying of a thf solution with hexane, and Figure 2 shows the molecular structure determined by a single crystal $\mathrm{X}$-ray analysis.

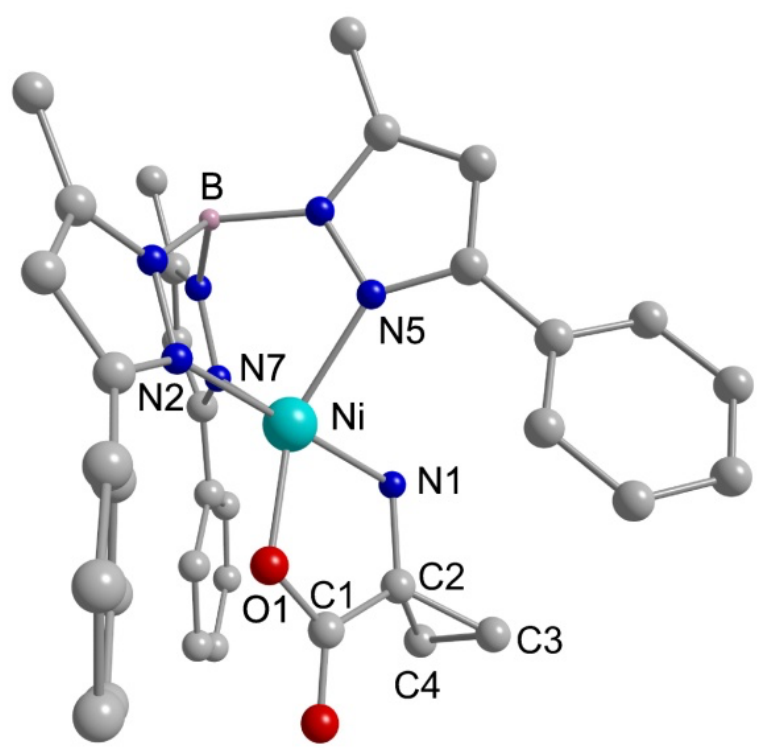


Figure 2. Molecular structure of $\mathbf{2}$ thf (all hydrogen atoms have been omitted for clarity). Selected bond lengths $(\AA)$ and angles $\left({ }^{\circ}\right)$ : Ni-O1 1.9585(11), Ni-N1 2.0859(14), Ni-N2 2.0993(13), Ni-N5 2.0698(13), Ni-N7 2.0510(13), O1-NiN1 82.19(5), N2-Ni-N5 87.29(5), N2-Ni-N7 90.03(5), N5-Ni N7 95.17(5), O1$\mathrm{Ni}-\mathrm{N} 2 \quad 95.59(5), \quad \mathrm{O} 1-\mathrm{Ni}-\mathrm{N} 5 \quad 146.53(5), \quad \mathrm{O} 1-\mathrm{Ni}-\mathrm{N} 7 \quad 118.12(5), \quad \mathrm{N} 1-\mathrm{Ni}-\mathrm{N} 2$ 175.66(5), N1-Ni-N5 92.51(5), N1-Ni-N7 94.31(5).

As expected the ACC ligand binds as a chelating ligand. The nickel(II) center is thus coordinated by the three $\mathrm{N}$-atoms of the $\mathrm{Tp}^{\mathrm{Me}, \mathrm{Ph}}$ ligand as well as by the amine and carboxylate functions of the O-deprotonated ACC creating a ligand sphere that is inbetween trigonal bipyramidal and square pyramidal $(\tau=0.48)$. While in previous models the $\mathrm{C}-\mathrm{C}$ bond of the cyclopropyl unit appeared shortened,,$^{[9]}$ such an effect was not noticeable in case of 2: The C3-C4 bond length in $2(1.496(3) \AA$ ) was almost identical with the one found for free $A C C^{[14]}(1.490-1.497 \AA)$.

Based on the striking resemblance of the IR spectra exhibited by $\mathbf{1}$ and $\mathbf{2}$ a corresponding structure is suggested also for 1 , which thus features one free coordination site for the potential binding and activation of $\mathrm{O}_{2}$ or alternative oxidants. ${ }^{[18]}$ Accordingly, reactivity studies were carried out. It has been suggested that a prerequisite for $\mathrm{O}_{2}$ reactivity is $\mathrm{E}_{1 / 2}\left(\mathrm{Fe}^{\mathrm{IIIII}}\right)<-0.1$ $\mathrm{V}$ vs $\mathrm{Fc}^{+} / \mathrm{Fc}^{\left[{ }^{[16]}\right.} \mathrm{A} \mathrm{CV}$ investigation of $\mathbf{1}$ dissolved in dichloromethane indicated a reversible redox event, but the oxidation and reduction peaks were separated by $410 \mathrm{mV}$ indicating reversible structural changes upon oxidation/reduction (see Supplementary information). The oxidation peak occurred at $0.03 \mathrm{~V}$, which appeared not negative enough for $\mathrm{O}_{2}$ reactivity. On the other hand reactivity trends observed in previous work for TpFe-based Dke1 models could not be rationalized on the basis of redox potentials, ${ }^{[17]}$ and indeed 1 was found to react with $\mathrm{O}_{2}$.

Complex 1 was dissolved in DMF and added to $\mathrm{O}_{2-}$ saturated DMF placed in hermetically sealed vials. Analysis of the headspace gas by $\mathrm{GC}$ revealed the presence of ethylene, and the conversion yield reached a maximum of ca. $17 \%$ after a few minutes at $70^{\circ} \mathrm{C}$. Importantly, no ethylene was detected when ACC alone (in form of its $\mathrm{NBu}_{4}{ }^{+}$salt) was placed in aerated DMF for one hour indicating that the observed activity is not due to free ACC (potentially released from the complex) in solution. Furthermore, ethylene production was found to be 3 times lower (conversion yields of ca. $6 \%$ ) when $\mathrm{Fe}\left(\mathrm{ClO}_{4}\right)_{2} \bullet \mathrm{xH}_{2} \mathrm{O}$ in combination with $\left(\mathrm{NBu}_{4}\right) \mathrm{ACC}$ was employed instead of complex 1 under the same conditions. Notably, the nickel complex 2 does not react with $\mathrm{O}_{2}$, which suggests an initiation of the reaction by binding of $\mathrm{O}_{2}$ at the iron center in the first step.

Under single turn-over conditions and in absence of ascorbate, Rocklin et al. found that only 0.35 mole of ethylene per mole of ACCO are formed, and hence they proposed that the electrons needed for catalysis are provided by a fraction of the initial ACCO enzyme. ${ }^{[6]}$ Also in case of our experiments it is conceivable that the required electrons are provided by a fraction of complex 1 therefore limiting the reaction yield as observed for the enzymatic system. Attempts to provide electrons by adding different reductants (ascorbate or benzoine) remained unsuccessful, though. To obtained information about the fate of the residual skeleton of 1 we have performed GC/MS studies with the gasphase after the reaction, which revealed $\mathrm{CO}_{2}$ as a further product, as one should expect. ${ }^{[19]}$ Monitoring the UV/Vis spectrum of a DMF solution of 1 with time at r.t. and at $70^{\circ} \mathrm{C}$ showed that after $\mathrm{O}_{2}$ addition the main changes (general increase of absorption in the range of $300-500 \mathrm{~nm}$ ) occur within 0-5 min. (see $\mathrm{SI})$. After this time the spectrum remains nearly constant displaying only discrete changes, while ethylene yield increases within ca. $2 \mathrm{~h}$. Hence, there is probably an initial fast step (perhaps only partially as part of an equilibrium), followed by a much slower reaction producing ethylene. At r.t. ethylene yield reaches a plateau at ca. $7 \%$. This suggests that a decomposition reaction competes with the productive path, which, however, can be accelerated to a significant extent by warming to $70^{\circ} \mathrm{C}(\rightarrow 17 \%)$.

For many $\mathrm{O}_{2}$ activating non-heme iron enzymes and models thereof the initial $\mathrm{O}_{2}$ binding step with formation of iron(III) superoxide intermediates has been found to be endergonic in theoretical investigations. The subsequent steps are usually exothermic but in case of low-molecular weight analogues often characterized by substantial barriers, which - together with the endergonic $\mathrm{O}_{2}$ binding step - decrease the reaction rates. If enzymes are considered, which - as the ACCO - in parallel to $\mathrm{O}_{2}$ consume electrons to reach substrate oxidation and feature peroxide intermediates, this problem can be circumvented by employing reduced forms of dioxygen, i.e. for instance $\mathrm{H}_{2} \mathrm{O}_{2}$ or Oatom transfer reagents. Significant ethylene production was observed when complex 1 was placed in the presence of $\mathrm{PhlO}$ or mCPBA. However, The latter reagents significantly oxidize ACC already in the absence of iron of complex (ca. $75 \%$ and $35 \%$ yield within 2-3 $\mathrm{h}$ respectively), so that their employment does not provide any information (see SI). Hence, different concentrations of hydrogen peroxide were tested, and interestingly, for a $0.5 \mathrm{mM}$ solution of complex 1 the ACC conversion into ethylene reaches $65 \%$ yield employing $10-20 \mathrm{mM}$ of hydrogen peroxide after $20 \mathrm{~min}$. Under the same conditions, ACC alone was hardly oxidized to produce ethylene (less than $2 \%$ conversion yield) confirming that the observed activity is not due to released ACC in solution. Also the reactivity of $\mathbf{2}$ towards $\mathrm{H}_{2} \mathrm{O}_{2}$ was found to be rather limited (less than $2 \%$ conversion yield), emphasizing the importance of the nature of the metal center. Finally, ethylene production from a $0.5 \mathrm{mM}$ solution of $\mathrm{Fe}\left(\mathrm{ClO}_{4}\right)_{2} \cdot \mathrm{xH}_{2} \mathrm{O} /\left(\mathrm{NBu}_{4}\right) \mathrm{ACC}$ in DMF in the presence of $10-20 \mathrm{mM} \mathrm{H} \mathrm{H}_{2}$ was found to be 6 times lower (conversion yields of ca. 10-12\%) than that observed for complex 1 , which demonstrates the importance also of the co-ligand to control the reactivity.

Altogether, these results imply that the observed ethylene production from complex 1 after reaction with $\mathrm{O}_{2}$ or hydrogen peroxide crucially depends on the suitability of the $\mathrm{Tp}^{\mathrm{Me}, \mathrm{Ph}} \mathrm{Fe}$ moiety to mimic the 2-His-1-carboxylate iron core within the ACCO. It has been rather well established that $\mathrm{H}_{2} \mathrm{O}_{2}$ can react with $\mathrm{Fe}^{\text {II }}$ or $\mathrm{Fe}^{\text {III }}$ complexes to provide the corresponding, reactive $\mathrm{Fe}^{\mathrm{III}}-\mathrm{OOH}$ intermediates. ${ }^{[15]}$ Reaction of $\mathrm{H}_{2} \mathrm{O}_{2}$ with complex 1 can thus be expected to first result in the oxidation of the $\mathrm{Fe}^{\text {II }}$ to $\mathrm{Fe}^{\text {III }}$ and then in the formation of the $\mathrm{Fe}^{\mathrm{III}}-\mathrm{OOH}$ intermediate. In the presence of dioxygen, the formation of the $\mathrm{Fe}^{\mathrm{III}}-\mathrm{OO}^{\circ}$ intermediate followed by one electron reduction by a further equivalent of 1 and protonation (for instance through residual water in DMF) could lead to a Fe $\mathrm{Fe}^{\mathrm{II}} \mathrm{-OOH}$ intermediate as well. Our results thus suggest that a $\mathrm{Fe}^{\mathrm{III}}-\mathrm{OOH}$ species is indeed involved in the catalytic cycle of the ACCO and that its formation probably precedes the oxidation of the bound substrate, in agreement with the two proposed mechanisms for the enzymatic system. 
In conclusion we have described here the first Fe"l-based low-molecular weight analogue which faithfully mimics the structure of the ACCO active site and at the same time also simulates the function. Indeed, this $\mathrm{Fe}^{\prime \prime}$ complex in contact with $\mathrm{O}_{2}$ shows an oxidase activity (17\%), which is remarkable as the enzymatic one is only ca. $35 \%$ under single turn-over conditions. Future studies, including various alternative oxygenation reagents, electron and proton donors as well as theoretical calculations, will focus on the further elucidation of the mechanism of this biomimetic oxidation.

\section{Acknowledgements}

We are grateful to the Humboldt-Universität zu Berlin for financial support. We also thank the Cluster of Excellence "Unifying Concepts in Catalysis" funded by the DFG for helpful discussions. The EU-COST Network (CM1305) on spin state reactivity is acknowledged for support.

Keywords: aminocyclopropane-1-carboxylic acid · oxidase · iron · enzyme model · oxygen

[1] F. Abeles, Ethylene in Plant Biology, Academic Press 1992

[2] D. O. Adams, S. F. Yang, Proc. Natl. Acad. Sci. USA 1979, 76, 170-174.

[3] Z. Zhang, J.-S. Ren, I. J. Clifton, C. J. Schofield, Chem. Biol. 2004, 11, 1383-1394.

[4] M. C. Pirrung, Acc. Chem. Res. 1999, 32, 711-718

[5] a) A. M. Rocklin, D. L. Tierney, V. Kofman, N. M. W. Brunhuber, B. M. Hoffman, R. E. Christoffersen, N. O. Reich, J. D. Lipscomb, L. Que, Jr., Proc. Natl. Acad. Sci. USA 1999, 96, 7905-7909; b) D. L. Tierney, A. M. Rocklin, J. D. Lipscomb, L. Que, Jr., B. M. Hoffman, J. Am. Chem. Soc. 2005, 127, 7005-7013; c) J. Zhou, A. M. Rocklin, J. D. Lipscomb, L. Que, Jr., E. I. Solomon, J. Am. Chem. Soc. 2002, 124, 4602-4609.

[6] A. M. Rocklin, K. Kato, H. W. Liu, L. Que Jr. and J. D. Lipscomb, J. Biol. Inorg. Chem., 2004, 9, 171-182.

[7] L. M. Mirica, J. P. Klinman, Proc. Natl. Acad. Sci. U. S. A., 2008, 105, 1814-1819.

[8] W. Ghattas, Z. Serhan, N. El Bakkali-Taheri, M. Réglier, M. Kodera, Y. Hitomi, A. J. Simaan, Inorg. Chem. 2009, 48, 3910-3912.

[9] W. Ghattas, C. Gaudin, M. Giorgi, A. Rockenbauer, A. J. Simaan, M. Réglier, Chem. Commun. 2006, 1027-1029.

[10] Y. Roux, W. Ghattas, F. Avenier, R. Guillot, A. J. Simaan, J.-P. Mahy, Dalton Trans. 2015, DOI: 10.1039/c5dt00347d.

[11] a) I. Siewert, C. Limberg, Angew. Chem. 2008, 120, 8071-8074; Angew. Chem. Int. Ed. 2008, 47, 7953-7956; b) M. Sallmann, I. Siewert, L.
Fohlmeister, C. Limberg, C. Knispel, Angew. Chem. 2012, 124, 22772280; Angew. Chem. Int. Ed. 2012, 51, 2234-2237.

[12] a) W. H. Armstrong, S. J. Lippard, J. Am. Chem. Soc. 1983, 105, 48374838; b) W. H. Armstrong, A. Spool, G. C. Papaefthymiou, R. B. Frankel, S. J. Lippard, J. Am. Chem. Soc. 1984, 106, 3653-3667; c) E. H. Ha, R. Y. N. Ho, J. F. Kisiel, J. S. Valentine, Inorg. Chem. 1995, 34, 2265-2266; d) S. Hikichi, T. Ogihara, K. Fujisawa, N. Kitajima, M. Akita, Y. Moro-oka, Inorg. Chem. 1997, 36, 4539-4547; e) E. L. Hegg, R. Y. N. Ho, L. Que, Jr., J. Am. Chem. Soc. 1999, 121, 1972-1973; f) M. P. Mehn, K. Fujisawa, E. L Hegg, L. Que, Jr., J. Am. Chem. Soc. 2003, 125, 7828-7842; g) T. K. Paine, H. Zheng, L. Que, Jr., Inorg. Chem. 2005, 44, 474-476; h) N. Burzlaff, Angew. Chem. 2009, 121, 5688-55690; Angew. Chem. Int. Ed. 2009, 48, 5580-5582; i) A. Mukherjee, M. Martinho, E. L. Bominaar, E. Münck, L. Que, Jr., Angew. Chem. Int. Ed. 2009, 48, 1780-1783.

[13] T. Tietz, C. Limberg, R. Stößer, B. Ziemer, Chem. Eur. J. 2011, 17, 10010-10020.

[14] a) M. C. Pirrung, J. Org. Chem. 1987, 52, 4179-4184; b) G. Valle, M. Crisma, C. Toniolo, E. M. Holt, M. Tamura, J. Bland, C. H. Stammer, Int. J. Pept. Protein Res. 1989, 34, 56-65.

[15] a) J.J. Girerd, F. Banse, A. J. Simaan, Structure and Bonding, 2000, 97, 145-177, Springer Verlag, New York Inc. b) M. Costas, M. P. Mehn, M. P. Jensen, L. Que, Jr., Chem. Rev. 2004, 104, 939-986; c) M. R. Bukowski, P. Comba, A. Lienke, C. Limberg, C. L. de Laorden, R. MasBallesté, M. Merz, L. Que Jr., Angew. Chem., 2006, 118, 3524-3528; Angew. Chem. Int. Ed. 2006, 45, 3446-3449; d) M. R. Bukowski, P. Comba, C. Limberg, M. Merz, L. Que Jr., T. Wistuba, Angew. Chem. 2004, 116, 1303-1307; Angew. Chem. Int. Ed., Engl. 2004, 43, 1283-1287; e) Y. M. Kim, K.-B. Cho, J. Cho, B. Wang, C. Li, S. Shaik, W. Nam, J. Am. Chem. Soc. 2013, 135, 8838-8841; f) L. V. Liu, S. Hong, J. Cho, W. Nam, E. I. Solomon J. Am. Chem. Soc., 2013, 135 , 3286-3299; g) J. Cho, S. Jeon, S. A. Wilson, L. V. Liu, E. A. Kang, J. J. Braymer, M. H. Lim, B. Hedman, K. O. Hodgson, J. S. Valentine, E. I. Solomon, W. Nam, Nature 2011, 478, 502-505.

[16] Y. M. Badiei, M. A. Siegler, D. P. Goldberg, J. Am. Chem. Soc. 2011, 133, 1274-1277.

[17] H. Park, M. M. Bittner, J. S. Baus, S. V. Lindeman, A. T. Fiedler, Inorg. Chem. 2012, 51, 10279-10289.

[18] For the proposal/detection of iron(III) superoxide intermediates compare: a) Y.-M. Lee, S. Hong, Y. Morimoto, W. Shin, S. Fukuzumi, W. Nam, J. Am. Chem. Soc. 2010, 132, 10668-10670. b) S. Hong, K. D. Sutherlin, J. Park, E. Kwon, M. A. Siegler, E. I. Solomon, W. Nam, Nat. Commun. 2014, 5, 5440-5447; F. Oddon, Y. Chiba, J. Nakazawa, T. Ohta, T. Ogura, S. Hikichi, Angew. Chem. 2015 doi: 10.1002/ange.201502367

[19] Cyanide - a further product of the natural process - could not be detected through characteristic bands in IR spectra recorded for the solution after the reaction or the solid product mixture after removal of all volatiles. 
Entry for the Table of Contents (Please choose one layout)

Layout 1:

\section{COMMUNICATION}

A ripening model: The depicted complex mimics the structure and the function of the ACCO. It reacts with both $\mathrm{O}_{2}$ and $\mathrm{H}_{2} \mathrm{O}_{2}$, respectively, to yield ethylene, which allows for inferences with respect to the enzymatic mechanism.

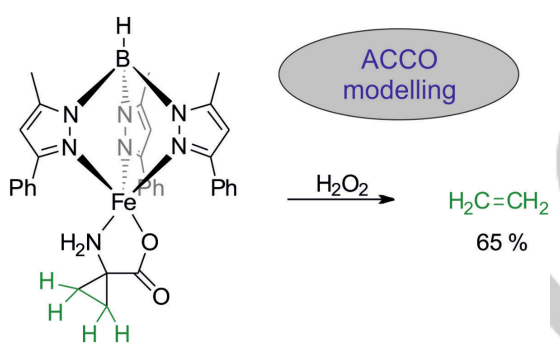

Madleen Sallmann, Fabio Oldenburg, Beatrice Braun, Marius Réglier, A. Jalila Simaan*, Christian Limberg*

Page No. - Page No.

A structural and functional model for the 1-aminocyclopropane-1carboxylic acid Oxidase 